\title{
Review
}

\section{Human Monoclonal Antibodies as Candidate Therapeutics Against Emerging Viruses and HIV-1*}

\author{
Zhongyu Zhu ${ }^{1 \#}$, Ponraj Prabakaran ${ }^{1,2 \#}$, Weizao Chen $^{1}$, Christopher C. Broder ${ }^{3}$, Rui Gong ${ }^{4 凶}$ and
} Dimiter S. Dimitrov ${ }^{1 凶}$

1. Protein Interactions Group, National Cancer Institute, National Institutes of Health, Frederick, Maryland 21702 , USA;

2. Basic Research Program, Science Applications International Corporation-Frederick, Inc., Frederick, Maryland 21702, USA;

3. Department of Microbiology and Immunology, Uniformed Services University, Bethesda, MD 20814, USA;

4. Center for Emerging Infectious Diseases, Wuhan Institute of Virology, Chinese Academy of Sciences, Wuhan, Hubei 430072, China)

More than 40 monoclonal antibodies (mAbs) have been approved for a number of disease indications with only one of these (Synagis) - for a viral disease, and not for therapy but for prevention. However, in the last decade novel potent mAbs have been discovered and characterized with potential as therapeutics against viruses of major importance for public health and biosecurity including Hendra virus $(\mathrm{HeV})$, Nipah virus $(\mathrm{NiV})$, severe acute respiratory syndrome coronavirus (SARS-CoV), Ebola virus (EBOV), West Nile virus (WNV), influenza virus (IFV) and human immunodeficiency virus type 1 (HIV-1). Here, we review such mAbs with an emphasis on antibodies of human origin, and highlight recent results as well as technologies and mechanisms related to their potential as therapeutics.

Antibodies; Viruses; SARS-CoV; Hendra virus; Nipah Virus

Monoclonal antibodies (mAbs) are currently successfully used for treatment of a number of diseases mostly cancer and immune disorders (Ashkenazi A, 2008; Carter P J, 2006; Casadevall A, et al., 2004; Dimitrov D S, 2012; Reichert J M, 2008; Schrama D, et al., 2006; Waldmann T A, 2003; Weiner L M, et al., 2009). The number of mAbs entering clinical trials per year has increased significantly since 1997 from just a few until late 1980s and to 12-14 from the late 1980s to 1996 to some 34 in 2006 (Reichert $\mathrm{J}$ M, 2008). The number of antibodies in preclinical development and in the discovery phase has also

Received: 2013-02-21, Accepted: 2013-03-07

* Foundation items: This project has been funded in whole or in part with federal funds from the National Cancer Institute, National Institutes of Health, under contract N01-CO-12400.

\# These authors contributed equally to this work.

$\triangle$ Corresponding authors.

Rui Gong: Phone: +86-27-87198232,

Fax: +86-27-87198352, Email: gongr@wh.iov.cn

Dimiter S. Dimitrov: Phone: +1-301-846-1352,

Fax:+1-301-846-5598, Email: dimiter.dimitrov@nih.gov increased significantly during the past decade. The success of the antibody-based therapeutics is mostly due to the use of basic concepts and methodologies developed during a major paradigm change in biological sciences several decades ago which resulted in dramatic improvement of key features of candidate therapeutic antibodies required for their approval by FDA-safety, efficacy and quality.

However, although more than $40 \mathrm{mAbs}$ have been approved for therapy of various diseases, the humanized mAb Synagis (palivizumab) (Scott L J, et al., 1999) has remained the only $\mathrm{mAb}$ against a viral disease approved by the FDA as a prophylactic measure against respiratory syncytial virus (RSV) infections in neonates and immunecompromised individuals. This situation has begun to change as increased numbers of mAbs against viral targets implicated in the outbreaks of SARS-CoV and other emerging viruses (Marasco W A, et al., 2007; Prabakaran P, et al., 2009; Ye J Q, et al., 2012) as well as against the HIV-1 and other infectious agents have been 
developed (Bonsignori M, et al., 2012; Gong R, et al., 2012; Kwong P D, et al., 2012), and some of them showed therapeutic potential for human clinical use. Very recently, Raxibacumab (Migone T S, et al., 2009) made history by being the first $\mathrm{mAb}$ approved by the FDA for therapy (and prophylaxis) of an infectious-related agent in this case inhaled anthrax. This approval is also important because it is the first one based only on animal models to demonstrate efficacy. Another mAb, m102.4 (Zhu $Z$, et al., 2008), also made history recently of being the first $\mathrm{mAb}$ administered on a compassionate basis to humans exposed to an infectious agent $(\mathrm{HeV})$ based on its efficacy in vitro and in animals (Bossart $\mathrm{K} \mathrm{N}$, et al., 2009; Bossart K N, et al., 2011).

Here we review human mAbs with potential as therapeutics against selected viruses which are important for public health and biosecurity along with their capability for causing pandemics such as some emerging viruses, e.g., SARS-CoV, and some variants of viruses which have existed for long time, e.g., H1N1 of IFV. We also highlight recent developments in the field of broadly neutralizing antibodies (bnAbs), engineered antibody domains (eAds) and bispecific fusion proteins against the HIV-1 which continues to be of great importance for public health as well as recently developed effective neutralization screening methods and antibody isolation techniques, design of structure-based antigenic probes and high-throughput 454 sequencing technology that have enabled rapid identification and characterization of anti-viral mAbs. A number of useful reviews on antiviral mAbs have been recently published (Euler Z, et al., 2012; Marasco W A, et al., 2007; Prabakaran P, et al., 2009; Ye J Q, et al., 2012).

\section{Potent broadly neutralizing human mAbs (bnAbs) against the SARS-CoV}

The SARS-CoV surface glycoprotein (S protein or S glycoprotein) mediates viral entry into the host cell and is composed of two subunits S1 and S2. The S1 is involved in the binding of the cellular receptor angiotensin converting enzyme 2 (ACE2), whereas the S2 facilitates the fusion between the viral and host-cell membranes. Several groups developed potent bnAbs targeting the $\mathrm{S}$ protein of SARS-CoV which were already reviewed in detail elsewhere (Coughlin M M, et al., 2012; Du L, et al., 2009; Prabakaran P, et al., 2009; Zhang M Y, et al., 2005). Some of them, e.g., S3.1, S215.13 and S230.15, were identified by the EBV transformation method (Traggiai E, et al., 2004; Yang Z Y, et al., 2005; Zhu Z, et al., 2007).
S230.15 showed potent inhibitory activity against isolates from the first and second outbreaks and from palm civets (Zhu Z, et al., 2007). Two other human mAbs, 201 and 68 , were derived from transgenic mice with human immunoglobulin genes; 201 was effective for postexposure prophylaxis in an animal model (Greenough $\mathrm{T}$ C, et al., 2005). Phage display technology has also been used to select effective mAbs against the $\mathrm{S}$ protein, including CR3014 (ter Meulen J, et al., 2006), CR3022 (ter Meulen J, et al., 2006), B1 (Duan J, et al., 2005), m396 (Prabakaran P, et al., 2006) and 80R (Hwang W C, et al., 2006). Both CR3014 and CR3022 bound to S1 domain and showed neutralization of SARS-CoV in a synergistic fashion such that CR3022 neutralized CR3014 escape viruses. B1 antibody is known to target the S2 domain within amino acids 1013-1189. The mAbs m396 and 80R blocked the binding of S1 to ACE2 and further crystallographic characterization of $\mathrm{m} 396$ and $80 \mathrm{R}$ in complex with the receptor binding domain (RBD) of $\mathrm{S} 1$ domain precisely identified the location of their epitopes (Hwang W C, et al., 2006; Prabakaran P, et al., 2006). m396 potently neutralized GD03 and representative isolates from the first SARS outbreak (Urbani, Tor2) and from palm civets (SZ3, SZ16). These two antibodies also protected mice challenged with the Urbani, or recombinant viruses bearing the GD03 and SZ16 S glycoproteins. Finally, $\mathrm{X}$-ray structural analyses of SARS-CoV RBD in complexes with m396 and 80R antibodies as well as the ACE2 (Li F, et al., 2005) reveals the common molecular mechanisms for their target binding as well as their specificity for different strains including the specific binding of $\mathrm{m} 396$ to GD03 strain. Both antibodies m396 and 80R competed with the ACE2 for binding to the RBD suggesting a mechanism of neutralization that involves interference with the SARS-CoV-ACE2 interaction. The antibody complex structures of $\mathrm{m} 396$ and $80 \mathrm{R}$ also shared a similar mode of RBD recognition as seen in the RBD complex structure of a neutralizing mouse mAb, F26G19, elicited by immunization with chemically inactivated SARS -CoV (Pak J E, et al., 2009).

Realizing the possibility of reemergence of SARS-CoV or any related virus such as the newly discovered human coronavirus (HCoV-EMC/2012) (van Boheemen S, et al., 2012), research on mAbs against the SARS-CoV is still continuing. Recently, new bnAbs, 4D4, 1F8 and 5E9, against highly conserved heptad repeat 1 (HR1) and HR2 of the SARS-CoV S2 were identified, and cocktail of these mAbs targeting different conserved regions of the $\mathrm{S}$ protein was shown to be more effective in neutralizing 
different SARS-CoV clinical isolates (Elshabrawy $\mathrm{H}$ A, et al., 2012). Also, random mutagenesis and DNA shuffling of 80R followed by bacterial display screening were used to generate a number of higher-affinity variants of $80 \mathrm{R}$ with equilibrium dissociation constants $\mathrm{K}_{\mathrm{D}}$ as low as 37 pM, a $>270$-fold improvement relative to that of the parental 80R (Rani M, et al., 2012).

Interestingly, in contrast to bnAbs against HIV-1, broad and potent neutralizing activity against the SARS-CoV does not require high level of somatic hypermutation (Chen $\mathrm{W}$, et al., 2010; Xiao X, et al., 2009). For example, m396 is much less somatically mutated than any of the known bnAbs against HIV-1. The maturation pathways for such mAbs are much less complex than those for bnAbs against HIV-1 and therefore their elicitation should be quicker and more effective. To find whether there are germline antibodies or antibodies with very low level of somatic hypermutations that could bind the $\mathrm{S}$ protein with high affinity, phage-displayed human cord blood-derived IgM libraries were recently constructed and panned against the SARS-CoV RBD which yielded a germlinelike antibody, m390, with only two mutations each in the $\mathrm{V}$ regions of the heavy and light chains and no mutations in the $\mathrm{D}$ and $\mathrm{J}$ regions (Chen $\mathrm{W}$, et al., 2012). The purified soluble Fab $\mathrm{m} 390$ bound to the $\mathrm{S}$ protein RBD with an $\mathrm{EC}_{50}$ of $50 \mathrm{nM}$. The neutralizing germline-like mAbs against the SARS-CoV could be useful for the design of effective vaccine immunogens and antibody based therapeutics.

\section{bn $\mathrm{Abs}$ against $\mathrm{HeV}$ and $\mathrm{NiV}$}

$\mathrm{HeV}$ and $\mathrm{NiV}$ are closely related emerging paramyxoviruses which are capable of causing severe lethal disease in both animals and humans (Eaton B T, et al., 2006). Currently, there are no approved therapeutics against them. $\mathrm{HeV}$ and $\mathrm{NiV}$ are enveloped viruses and have two membrane glycoproteins, an attachment (G) glycoprotein which binds to the virus receptors ephrinB2 and ephrinB3, and a fusion (F) glycoprotein, which facilitates the fusion of virus and host cell membranes. Antibodies specific for either the $\mathrm{F}$ or $\mathrm{G}$ glycoproteins can neutralize virus, but it is those antibodies specific for the G glycoproteins which appear to be the dominant target antigen for neutralizing antibodies. Potent neutralizing human mAbs targeting the viral envelope glycoprotein $\mathrm{G}$ were identified by using a highly purified, oligomeric, soluble $\mathrm{HeV} \mathrm{G} \mathrm{(sG)} \mathrm{glycoprotein} \mathrm{as}$ the antigen for screening of a large naïve human phage-display library (Zhu Z, et al., 2006). Seven Fabs, m101-7, which inhibited, to various degrees, cell fusion mediated by the $\mathrm{HeV}$ were selected. One of these Fabs, $\mathrm{m} 102$, exhibited high level of cross-reactivity to both $\mathrm{HeV}$ and NiV G and was further in vitro affinity matured to m102.4 by light chain shuffling (Zhu Z, et al., 2008). The matured m102.4 showed significantly improved neutralizing activity against both $\mathrm{NiV}$ and $\mathrm{HeV}$ in vitro with IC50s below, respectively, 0.04 and $0.6 \mu \mathrm{g} / \mathrm{mL}$. After conversion to an immunoglobulin G1 (IgG1) format, m102.4 demonstrated exceptional cross-reactive neutralizing capability in vitro and completely protected ferrets from lethal NiV-mediated disease when administered 10 hours after virus challenge (Bossart $\mathrm{K} \mathrm{N}$, et al., 2009). The crystal structures of the $\mathrm{G}$ glycoprotein in complex with ephrin-B2 (Bowden T A, et al., 2008) and ephrin-B3 (Xu $\mathrm{K}$, et al., 2008) as well as with m102.3 antibody, a clonal variant of m102.4 (Nikolov D B, et al., Submitted), reveal high level of overlapping between the mAb epitope and the receptor binding site suggesting that mimicry of the receptor recognition is a major molecular mechanism of the m102.4 neutralizing activity and cross-reactivity.

Recently, m102.4 was tested in African green monkeys (AGMs) infected with $\mathrm{HeV}$ (Bossart K N, et al., 2011). Fourteen AGMs were challenged intratracheally with a lethal dose of $\mathrm{HeV}$, and 12 of them were infused twice with a 100-mg dose of m102.4 beginning at either 10, 24, or 72 hours after infection and again 48 hours later. The $\mathrm{HeV}$-mediated disease and its associated pathogenic processes in AGMs essentially mirrored the outcomes observed in $\mathrm{HeV}$ infected humans. Also, the pharmacokinetics of m102.4 in the AGM was similar to previously published human immunoglobulin half-life data for non-human primates. Most importantly, m102.4 protected all 12 AGMs from illness $(10 \mathrm{hr} / 72 \mathrm{hr}$ and $24 \mathrm{hr} / 72 \mathrm{hr})$ and fatal disease (72hr/d5) when administered following a lethal $\mathrm{HeV}$ challenge. The untreated control subjects succumbed to disease on day 8 post infection. Although all animals in the 72-hour treatment group exhibited neurological signs of disease, they started to recover by day 16 after infection. These results demonstrated successful post-exposure in vivo efficacy by a hmAb, m102.4, against $\mathrm{HeV}$ and offered a glimpse of the potential impact a hmAb can have on human disease due to deadly viral infection. Based on its high efficacy in two animal models and its fully human nature, m102.4 was administered on a compassionate basis to four patients in Australia who were exposed to $\mathrm{HeV}$. There were no side effects. One of the patient who received the $\mathrm{mAb}$ too late (he was in coma) and too little (100 mg) died but the other three are still healthy. These results show that m102.4 exhibits potent cross-reactive 
neutralizing activities against both Nipah virus and Hendra virus, and could be useful for the therapy, prophylaxis, and diagnosis, and as a research reagent and aid in the development of vaccines.

\section{Antibody-based candidate therapeutics against EBOV,} WNV and IFV

In recent years mAbs against EBOV (Filoviridae), WNV (Flaviviridae) and IFV (Orthomyxoviridae) have received much attention as potential therapeutics both for prophylaxis and therapy of infected humans. EBOV envelope glycoprotein GP1 mediates the attachment to target cells while GP2 drives fusion of the viral membrane with the endosomal membrane of the target cell. There are five antigenically distinct EBOVs, Bundibugyo virus, Sudan virus, Reston virus, Taï Forest virus, and Zaire virus, which can cause hemorrhagic fever in humans and/or non-human primates. Several protective mAbs were mapped to five distinct epitopes on the Ebola glycoprotein (Wilson J A, et al., 2000). Antibody 13F6 (Lee J E, et al., 2008) and its modified version of a human recombinant antibody, h-13F6, were shown to protect mice against a lethal challenge of EBOV. Another antibody, KZ52, was isolated from the bone marrow of a human survivor of EBOV infection; it targets the complex of GPland GP2 (Lee J E, et al., 2008). KZ52 neutralized EBOV in vitro and protected from lethal EBOV challenge in a rodent model, but not in monkeys (Friedrich B M, et al., 2012). Structural basis for differential neutralization and antibody-mediated neutralization mechanisms of EBOVs have now been well established (Bale S, et al., 2012; Shedlock D J, et al., 2010). In a recent study, two human-mouse chimeric mAbs, ch133 and ch226, which have strong neutralizing activity against Zaire ZEBOV exhibited partial protective activity in a rhesus macaque model of Ebola hemorrhagic fever (Marzi A, et al., 2012). In another study, a total of $8 \mathrm{mAbs}$ against the EBOV were produced using traditional hybridoma cell fusion technology, and characterized by ELISA using ZEBOV VLPs. All $8 \mathrm{mAbs}$ bound to three distinct epitope regions, and a mouse model showed that these mAbs improved survival rates by $33 \%-100 \%$ against a high dose lethal challenge with mouse-adapted ZEBOV (Qiu X, et al., 2011). These results shed light on the antibody-mediated neutralization of EBOV and have implications for novel therapeutic and vaccine strategies.

$\mathrm{WNV}$ is a mosquito-borne flavivirus closely related to the human epidemic-causing dengue, yellow fever and Japanese encephalitis viruses. Previously, humanized mAb,
E16, was developed targeting the viral envelope, which blocked infection of cells by ten different strains of WNV in vitro, including the original lineage II strain which was isolated in 1937 (Oliphant T, et al., 2005). It appears that both affinity and the precise epitope are important determinants of the WNV neutralization by mAbs (Sanchez M D, et al., 2005). The X-ray structure of the Fab E16-antigen complex showed that the mAb engages 16 residues positioned on four loops of DIII, a consensus neutralizing epitope sequence conserved in WNV and distinct in other flaviviruses (Nybakken G E, et al., 2005). Another human mAb, CR4354, which was isolated from a patient, neutralizes WNV infection at a postattachment stage in the viral life-cycle. This mAb blocks virus fusion with liposomes in vitro and recognizes virus particles, but not the recombinant E ectodomain. This suggests that its epitope requires an oligomeric $\mathrm{E}$ arrangement present only in virions or subviral particles (SVP). Further analysis of neutralization escape mutants identified residue Lys136 as part of the CR4354 epitope that is close to the flexible DI-DII hinge interface and is found to be critical for antibody binding (Kaufmann B, et al., 2010). These anti-WNV complex structures are helpful to analyze the complete epitope and understand the mechanism by which viral fusion is inhibited for WNV and also antibody-mediated neutralization of other related flaviviruses such as yellow fever, Japanese encephalitis, and tickborne encephalitis viruses.

Influenza is mainly caused by infection with either influenza A (IFVA) or influenza B (IFVB) viruses. IFVAs are considered to be more dangerous than IFVB viruses as the former have the capacity to mutate into deadly pandemic strains, although the latter also have significantly contributed to the annual influenza related illness in humans. IFVAs are further classified by subtype on the basis of the two main surface glycoproteins: hemagglutinin (HA) and neuraminidase (NA). Current subtypes of IFVA viruses that are in circulation worldwide include the pandemic 2009 H1N1 (swine influenza), the seasonal H1N1, H3N2 and the highly virulent H5N1 (avian influenza or bird flu). Previously, a panel of 13 human mAbs from combinatorial display libraries that were constructed from human $\operatorname{IgM}(+)$ memory $\mathrm{B}$ cells of recent influenza vaccinees were isolated (Throsby M, et al., 2008). These mAbs have broad heterosubtypic neutralizing activity against antigenically diverse H1, H2, H5, H6, H8 and H9 influenza subtypes. The most potent mAb from this panel, CR6261, was protective in mice when given before and after lethal 
H5N1 or H1N1 challenge. In another study, using a human non-immune antibody phage-display library panned by the H5 HA ectodomain, ten mAbs were selected and found effective against all group 1 influenza viruses tested, including $\mathrm{H} 5 \mathrm{~N} 1$ and the $\mathrm{H} 1 \mathrm{~N}$ (Sui J, et al., 2009). Further, the crystal structure of one of those mAbs (F10) bound to $\mathrm{H} 5$ suggests possible explanation of its neutralizing mechanism-F10 blocks infection by inserting its heavy chain into a conserved pocket in the stem region of H5, thus preventing membrane fusion. Interestingly, both CR6261 and F10 use the same variable heavy chain gene IGHV1-69 and similar mode of antigen recognition by binding to a conserved epitope in helix A of the HA stem (Ekiert D C, et al., 2009). Another mAb, CR8020, isolated from human memory B cells binds to HAs of several group 2 subtypes including $\mathrm{H} 3$ and $\mathrm{H} 7$ (Ekiert D C, et al., 2011). The complex structure of CR8020 with H3 HA showed how this antibody binds to an epitope in the HA stem which is unique and closer to viral membrane as compared to the group 1 antibodies. FI6 is the first $\mathrm{mAb}$ antibody isolated using a novel plasma cell culture method which was found to bind to both group 1 (H1) and group 2 (H3) HAs (Corti D, et al., 2011). The complex crystal structures of FI6 with H1and H3 HAs from group 1 and group 2, respectively, revealed a quaternary epitope using both heavy and light chains CDRs. Also, another antibody, CR9114, identified from a phage library was discovered which binds to both IFVA and IFVB HAs (Dreyfus C, et al., 2012). The mAbs targeting different globular head sites are also known, for example, FE17 (Corti D, et al., 2010) and CH65 (Whittle J R, et al., 2011) which target the calcium binding site and sialic acid-biding pocket respectively and are able to neutralize different viruses in addition to H1N1. The B cell epitopes identified from these studies could accelerate the design of improved influenza vaccines eliciting bnAbs as well as antibody-based therapies for treatment of IFVs.

Several mAbs from human and other organisms targeting many viruses such as hepatitis $\mathrm{C}$ virus (HCV) (Meuleman $\mathrm{P}$, et al., 2012), norovirus (NV) (Lindesmith L C, et al., 2012), rotavirus (RV) (Higo-Moriguchi K, et al., 2004), Marburg virus (MARV) (Kajihara M, et al., 2012), Junin virus (JUNV) (Nakauchi M, et al., 2009), herpes simplex virus type 2 (HSV-2) (Bugli F, et al., 2004), human cytomegalovirus (HCMV) (Ohta A, et al., 2009), Chikungunya virus (CHIKV) (Fric J, et al., 2013), Crimean- Congo hemorrhagic fever virus (CCHFV) (Saijo M, et al., 2005) and vaccinia virus (VACV) (Meng X, et al., 2012) have also been developed, and many of them were used as diagnostics or tested in animal models as therapeutics which could have potential clinical use in case of epidemic outbreaks or terror attacks.

\section{bnAbs, engineered antibody domains and bispecific fusion proteins against HIV-1}

Only four bnAbs capable of neutralizing multiple primary HIV-1 isolates were identified during the first two decades of HIV-1 research; these antibodies target three sites on the HIV-1 envelope glycoprotein - glycan site on gp120 recognized by 2G12 (Trkola A, et al., 1996), the CD4 binding site (CD4bs) of gp120 recognized by b12 (Burton D R, et al., 1994), and the membrane proximal external region (MPER) site of gp41 recognized by 2F5 (Muster T, et al., 1993) and 4E10 (Stiegler G, et al., 2001). All these antibodies exhibit high levels of somatic mutation suggesting the importance of understanding their maturation pathways and properties of putative germline predecessors (Dimitrov D S, 2010; Xiao X, et al., 2009; Xiao X D, et al., 2009). In addition to these bnAbs, several mAbs with intermediate neutralizing activity were isolated and characterized including the CD4bs mAbs (Chen L, et al., 2009; Prabakaran P, et al., 2006; Zhang M Y, et al., 2004); F105, b13, m14 and m18; CoRbs (CD4i) mAbs (Darbha R, et al., 2004; Huang C C, et al., 2005; Huang C C, et al., 2004; Kwong P D, et al., 1998); 17b, 48d, 47e, E51, 412d and X5. X-ray structural analysis combined with binding experiments and modeling studies of many of these mAbs showed that subtle differences in antigen combining sites and recognition mechanisms, when compared to that observed with bnAbs, are crucial for HIV-1 neutralization.

Recently about two dozens of bnAbs have been isolated from HIV-1 patients using direct neutralization screening of individual $\mathrm{B}$ cells, designed probe-based $\mathrm{B}$ cell isolation and in combination with deep sequencing (Bonsignori M, et al., 2012; Kwong P D, et al., 2012; Verkoczy L, et al., 2011). These include two mAbs targeting the CD4bs, VRC01 and VRC02, which were identified by isolation of single $\mathrm{mAb}$-producing $\mathrm{B}$ cells against an antigenically resurfaced HIV-1 gp120 specific for the structurally conserved site of initial CD4 receptor binding. Neutralization screening of individual $\mathrm{B}$ cell methods were also used to identify several new bnAbs-PG9, PG16, CH01-04 and PGT141-145 targeting gp120 conformational or quaternary epitope; PGT121, PGT128 and PGT135 targeting epitopes on glycan-V3 site of gp120; HJ16 on near CD4bs and 10E8 on MPER, which have been recently reviewed in elsewhere (Bonsignori M, et al., 2012; Kwong P D, et al., 
2012; van Gils M J, et al., 2013). Also, fluorescence activated cell sorting (FACS) and 454 deep sequencing have been used to identify 3BNC117 and 12A12 which target the CD4bs. Further, VRC-CH31 and VRC-PG04 families of bnAbs by using resurfaced gp120 core, and NIH45-46 by structure-based design were also identified. Notably, an MPER specific antibody m66.6 which is significantly less divergent from their germline counterparts than other bnAbs was recently identified from a phage displayed immune library constructed using the antibody gene repertoire derived from a HIV patient whose serum antibodies showed broadly cross reactive neutralization activity and specific binding activity to MPER peptide (Zhu Z, et al., 2011). The "antibodyome" approach (Dimitrov D S, 2010) in studying the origin, diversity and maturation pathways of human antibodies that neutralize the HIV-1 has been made possible by 454 antibody sequencing despite the significant challenges due to errors and limitations of the methods involved (Prabakaran P, et al., 2011). The 454 analysis could also be useful to identify less somatically mutated bnAbs and/or antibody maturation intermediates that may be useful to elucidate the mechanism of initiating immune responses leading to the ultimate development of bnAbs. Recently, germlinelike or less-somatically mutated $\mathrm{V}$ genes in the human antibody repertoires of healthy humans to find antibody intermediates corresponding to known bnAbs (Prabakaran P, et al., 2012) as well as an acutely HIV-1 infected patient (Chen W, et al., 2012) were identified by using 454 sequencing. Thus, the applications of new technologies are useful in exploring B cell ontogenies and clonal lineages which could provide insights into the development of bnAbs and template design of novel HIV-1 vaccine immunogens (Dimitrov D S, 2010; Haynes B F, et al., 2012; Kwong P D, et al., 2012).

Engineered antibody domains (eAds, 11-15 kDa) could be more effective than full-size antibodies particularly for targeting the HIV-1, which impedes recognition of bnAbs by steric occlusion of the conserved epitopes on the Env as one of the strategies to evade neutralizing immune responses. M36 is the first reported human VH domainbased eAd $(\sim 15 \mathrm{kDa})$ which targets a sterically restricted CD4i epitope and potently neutralizes genetically diverse HIV-1 isolates in vitro (Chen W, et al., 2008) and in humanized mice (Harris Goldstein et al, unpublished). Several variable domains of camelid heavy chain antibodies, $\mathrm{V}_{\mathrm{H}} \mathrm{Hs}$, selected from libraries constructed by immunized camelids by HIV-1 Env targeting the CD4bs or CXCR4 (Strokappe N, et al., 2012), and a single domain antibody from llama targeting the HIV-1 nonstructural protein Nef (Bouchet J, et al., 2011) were also identified and characterized. Recently, $\mathrm{CH} 2$ domains (second domain of IgG heavy chain region) have been used as a scaffold for eAd library construction; they contain binding sites or partial binding sites of various Fc receptors such as the neonatal Fc receptor, Fc gamma receptors (Fc $\gamma \mathrm{Rs}$ ) and complement $\mathrm{Clq}$ which extend the half-life and are involved in stability and effector functions of full-size antibodies in vivo (Dimitrov D S, 2009). Thus CH2-based eAds could be potentially developed into nanoantibodies with small size but still bearing the features and effector functions of the full-size IgGs. For example, a large $\left(5 \times 10^{10}\right.$ members $)$ phage-displayed $\mathrm{CH} 2$ domain library (in which mutation of all residues in its two loops (BC and FG) to four residues (Y, A, D, or S)) yielded several binders against HIV-1; the highest-affinity binder, mla1, specifically recognizes a highly conserved CD4i epitope overlapping with that of $\mathrm{m} 36$ and neutralizes seven of nine HIV-1 isolates from different clades (Xiao X, et al., 2009). Further, a multi-step PCR method allowing the precise replacement of loop FG by human complementarity determining region 3 of the heavy chain (CDR H3s) from another library along with limited mutagenesis of loops $\mathrm{BC}$ and $\mathrm{DE}$ of $\mathrm{CH} 2$ domain was developed and used for generation of an eAd phage-displayed library. Panning of this library against an HIV-1 gp41 MPER peptide resulted in selection of a binder, m2a1, which neutralizes HIV-1 isolates from different clades with modest activity and retains the $\mathrm{m} 01 \mathrm{~s}$ capability of binding to FcRn (Gong R, et al., 2012). This result indicates that bispecific/bifunctional engineered antibody domains could be developed using the $\mathrm{CH} 2$ domain based eAds to interact noncompetitively with an HIV-1 neutralizing epitope and FcRn which could mimic the function of full-size antibodies (binding to antigen as well as FcRn). Recently, human soluble monomeric IgG1 Fcs (mFcs) were constructed using a combination of structure-based rational protein design and multiple screening strategies (Ying $\mathrm{T}$, et al., 2012). These mFcs were highly soluble and retained binding to human FcRn comparable with that of Fc. Taken together, $\mathrm{CH} 2$ domain based eAds as well as mFcs are useful in the development of potential antiviral therapeutics, and could be used as fusion proteins to make novel types of Ab-based therapeutics of small size and long half-lives. Although there has been some success already in developing eAds based on human fibronectin domain (FN3) (Jacobs S A, et al., 2012; Koide A, et al., 2012), camelid $\mathrm{V}_{\mathrm{H}} \mathrm{H}$ (Deschacht 
N, et al., 2010) and Shark Variable New Antigen Receptor (VNAR) domain (Fennell B J, et al., 2010), the $\mathrm{CH} 2$-based eAds and mFes offer unique biophysical properties and biological functions which could be useful for therapeutic applications.

\section{Conclusions}

Despite major obstacles arising from target heterogeneity and strategies to evade antibody immune responses of emerging viruses, effective human mAbs for the prophylaxis and treatment of viral diseases have now turned into reality. Recent examples of the Raxibacumab approval by FDA for inhalational anthrax therapy and the use of the human mAb m102.4 in humans for postexposure prophylaxis are promising for potential development of human therapeutic mAbs against viruses. In addition, recent discovery of potent bnAbs from HIV-1 patients, eAds targeting conserved epitopes in sterically occluded regions, highly potent bispecific fusion proteins based on eAds as well as understanding of antibodymediated neutralizing mechanisms and maturation pathways of bnAbs could be useful for therapeutic applications and/or for providing insights in vaccine development.

\section{Acknowledgements}

We thank the Intramural AIDS Targeted Antiviral Program of NIH the U.S.-China Program for Biomedical Research Cooperation and the Wuhan Key Laboratory on Emerging Infectious Diseases and Biosafety for support. The content of this publication does not necessarily reflect the views or policies of the Department of Health and Human Services, nor does mention of trade names, commercial products, or organizations imply endorsement by the U.S. Government.

\section{References}

Ashkenazi A. 2008. Directing cancer cells to self-destruct with pro-apoptotic receptor agonists. Nature Reviews Drug Discovery, 7: 1001-1012.

Bale S, Dias J M, Fusco M L, Hashiguchi T, Wong A C, Liu T, Keuhne A I, Li S, Woods V L, Jr., Chandran K, Dye J M, and Saphire E O. 2012. Structural basis for differential neutralization of ebolaviruses. Viruses, 4: 447-470.

Bonsignori M, Alam S M, Liao H X, Verkoczy L, Tomaras G D, Haynes B F, and Moody M A. 2012. HIV-1 antibodies from infection and vaccination: insights for guiding vaccine design. Trends Microbiol, 20: 532-539.

Bossart K N, Zhu Z, Middleton D, Klippel J, Crameri G, Bingham J, McEachern J A, Green D, Hancock T J, Chan Y P, Hickey A C, Dimitrov D S, Wang L F, and Broder C C. 2009. A neutralizing human monoclonal antibody protects against lethal disease in a new ferret model of acute nipah virus infection. PLoS Pathog, 5: e1000642.
Bossart K N, Geisbert T W, Feldmann H, Zhu Z, Feldmann F, Geisbert J B, Yan L, Feng Y R, Brining D, Scott D, Wang Y, Dimitrov A S, Callison J, Chan Y P, Hickey A C, Dimitrov D S, Broder C C, and Rockx B. 2011. A neutralizing human monoclonal antibody protects african green monkeys from hendra virus challenge. Sci Transl Med, 3: 105ra103.

Bouchet J, Basmaciogullari S E, Chrobak P, Stolp B, Bouchard N, Fackler O T, Chames P, Jolicoeur P, Benichou S, and Baty D. 2011. Inhibition of the Nef regulatory protein of HIV-1 by a single-domain antibody. Blood, 117: 3559-3568.

Bowden T A, Aricescu A R, Gilbert R J, Grimes J M, Jones E Y, and Stuart D I. 2008. Structural basis of Nipah and Hendra virus attachment to their cell-surface receptor ephrin-B2. Nat Struct Mol Biol, 15: 567-572.

Bugli F, Manzara S, Torelli R, Graffeo R, Santangelo R, Cattani P, and Fadda G. 2004. Human monoclonal antibody fragment specific for glycoprotein $\mathbf{G}$ in herpes simplex virus type 2 with applications for serotype-specific diagnosis. J Clin Microbiol, 42: 1250-1253.

Burton D R, Pyati J, Koduri R, Sharp S J, Thornton G B, Parren P W, Sawyer L S, Hendry R M, Dunlop N, Nara P L, and et al. 1994. Efficient neutralization of primary isolates of $\mathrm{HIV}-1$ by a recombinant human monoclonal antibody. Science, 266: 1024-1027.

Carter P J. 2006. Potent antibody therapeutics by design. Nature Reviews Immunology, 6: 343-357.

Casadevall A, Dadachova E, and Pirofski L. 2004. Passive antibody therapy for infectious diseases. Nature Reviews Microbiology, 2: 695-703.

Chen L, Kwon Y D, Zhou T, Wu X, O'Dell S, Cavacini L, Hessell A J, Pancera M, Tang M, Xu L, Yang Z Y, Zhang M Y, Arthos J, Burton D R, Dimitrov D S, Nabel G J, Posner M R, Sodroski J, Wyatt R, Mascola J R, and Kwong P D. 2009. Structural basis of immune evasion at the site of CD4 attachment on HIV-1 gp120. Science, 326: 1123-1127.

Chen W, Zhu Z, Feng Y, and Dimitrov D S. 2008. Human domain antibodies to conserved sterically restricted regions on gp120 as exceptionally potent cross-reactive HIV-1 neutralizers. Proc Natl Acad Sci U S A, 105: 17121-17126.

Chen W, Prabakaran P, Zhu Z, Feng Y, Streaker E D, and Dimitrov D S. 2012. Characterization of human IgG repertoires in an acute HIV-1 infection. Exp Mol Pathol, 93: 399-407.

Chen W, Streaker E D, Russ D E, Feng Y, Prabakaran P, and Dimitrov D S. 2012. Characterization of germline antibody libraries from human umbilical cord blood and selection of monoclonal antibodies to viral envelope glycoproteins: Implications for mechanisms of immune evasion and design of vaccine immunogens. Biochem Biophys Res Commun, 417: 1164-1169.

Chen W, Zhu Z, Liao H, Quinnan G V, Jr., Broder C C, Haynes B F, and Dimitrov D S. 2010. Cross-Reactive Human IgM-Derived Monoclonal Antibodies that Bind to HIV-1 Envelope Glycoproteins. Viruses, 2: 547-565.

Corti D, Suguitan A L, Jr., Pinna D, Silacci C, Fernandez-Rodriguez B M, Vanzetta F, Santos C, Luke C J, Torres-Velez F J, Temperton N J, Weiss R A, Sallusto F, Subbarao K, and Lanzavecchia A. 2010. Heterosubtypic neutralizing antibodies are produced by individuals immunized with a seasonal influenza vaccine. J Clin Invest, 120: 1663-1673.

Corti D, Voss J, Gamblin S J, Codoni G, Macagno A, Jarrossay D, Vachieri S G, Pinna D, Minola A, Vanzetta F, Silacci C, 
Fernandez-Rodriguez B M, Agatic G, Bianchi S, Giacchetto-Sasselli I, Calder L, Sallusto F, Collins P, Haire L F, Temperton N, Langedijk J P, Skehel J J, and Lanzavecchia A. 2011. A neutralizing antibody selected from plasma cells that binds to group 1 and group 2 influenza A hemagglutinins. Science, 333: 850-856.

Coughlin M M, and Prabhakar B S. 2012. Neutralizing human monoclonal antibodies to severe acute respiratory syndrome coronavirus: target, mechanism of action, and therapeutic potential. Rev Med Virol, 22: 2-17.

Darbha R, Phogat S, Labrijn A F, Shu Y, Gu Y, Andrykovitch M, Zhang M Y, Pantophlet R, Martin L, Vita C, Burton D R, Dimitrov D S, and Ji X. 2004. Crystal structure of the broadly cross-reactive HIV-1-neutralizing Fab X5 and fine mapping of its epitope. Biochemistry, 43: 1410-1417.

Deschacht N, De Groeve K, Vincke C, Raes G, De Baetselier P, and Muyldermans S. 2010. A novel promiscuous class of camelid single-domain antibody contributes to the antigen-binding repertoire. J Immunol, 184: 5696-5704.

Dimitrov D S. 2009. Engineered CH2 domains (nanoantibodies). Mabs, 1: 26-28.

Dimitrov D S. 2010. Therapeutic antibodies, vaccines and antibodyomes. Mabs, 2: 347-356.

Dimitrov D S. 2012. Therapeutic proteins. Methods Mol Biol, 899: $1-26$.

Dreyfus C, Laursen N S, Kwaks T, Zuijdgeest D, Khayat R, Ekiert D C, Lee J H, Metlagel Z, Bujny M V, Jongeneelen M, van der Vlugt R, Lamrani M, Korse H J, Geelen E, Sahin O, Sieuwerts M, Brakenhoff J P, Vogels R, Li O T, Poon L L, Peiris M, Koudstaal W, Ward A B, Wilson I A, Goudsmit J, and Friesen R H. 2012. Highly conserved protective epitopes on influenza B viruses. Science, 337: 1343-1348.

Du L, He Y, Zhou Y, Liu S, Zheng B J, and Jiang S. 2009. The spike protein of SARS-CoV--a target for vaccine and therapeutic development. Nat Rev Microbiol, 7: 226-236.

Duan J, Yan X, Guo X, Cao W, Han W, Qi C, Feng J, Yang D, Gao G, and Jin G. 2005. A human SARS-CoV neutralizing antibody against epitope on S2 protein. Biochem Biophys Res Commun, 333: 186-193.

Eaton B T, Broder C C, Middleton D, and Wang L F. 2006. Hendra and Nipah viruses: different and dangerous. Nat Rev Microbiol, 4 23-35.

Ekiert D C, Bhabha G, Elsliger M A, Friesen R H, Jongeneelen M, Throsby M, Goudsmit J, and Wilson I A. 2009. Antibody recognition of a highly conserved influenza virus epitope. Science, 324: 246-251.

Ekiert D C, Friesen R H, Bhabha G, Kwaks T, Jongeneelen M, Yu W, Ophorst C, Cox F, Korse H J, Brandenburg B, Vogels R, Brakenhoff J P, Kompier R, Koldijk M H, Cornelissen L A, Poon L L, Peiris M, Koudstaal W, Wilson I A, and Goudsmit J. 2011. A highly conserved neutralizing epitope on group 2 influenza A viruses. Science, 333: 843-850.

Elshabrawy H A, Coughlin M M, Baker S C, and Prabhakar B S. 2012. Human Monoclonal Antibodies against Highly Conserved HR1 and HR2 Domains of the SARS-CoV Spike Protein Are More Broadly Neutralizing. PLoS ONE, 7: e50366.

Euler Z, and Schuitemaker H. 2012. Cross-reactive broadly neutralizing antibodies: timing is everything. Front Immunol, 3: 215.

Fennell B J, Darmanin-Sheehan A, Hufton S E, Calabro V, Wu L, Muller M R, Cao W, Gill D, Cunningham O, and Finlay W J. 2010.
Dissection of the IgNAR $V$ domain: molecular scanning and orthologue database mining define novel IgNAR hallmarks and affinity maturation mechanisms. J Mol Biol, 400: 155-170.

Fric J, Bertin-Maghit S, Wang C I, Nardin A, and Warter L. 2013. Use of human monoclonal antibodies to treat chikungunya virus infection. J Infect Dis, 207: 319-322

Friedrich B M, Trefry J C, Biggins J E, Hensley L E, Honko A N, Smith D R, and Olinger G G. 2012. Potential vaccines and post-exposure treatments for filovirus infections. Viruses, 4: 1619-1650.

Gong R, Chen W, and Dimitrov D S. 2012. Candidate antibody-based therapeutics against HIV-1. BioDrugs, 26: 143-162.

Gong R, Wang Y, Ying T, and Dimitrov D S. 2012. Bispecific Engineered Antibody Domains (Nanoantibodies) That Interact Noncompetitively with an HIV-1 Neutralizing Epitope and FcRn. PLoS ONE, 7: e42288.

Greenough T C, Babcock G J, Roberts A, Hernandez H J, Thomas W D, Jr., Coccia J A, Graziano R F, Srinivasan M, Lowy I, Finberg R W, Subbarao K, Vogel L, Somasundaran M, Luzuriaga K, Sullivan J L, and Ambrosino D M. 2005. Development and characterization of a severe acute respiratory syndrome-associated coronavirusneutralizing human monoclonal antibody that provides effective immunoprophylaxis in mice. J Infect Dis, 191: 507-514.

Haynes B F, Kelsoe G, Harrison S C, and Kepler T B. 2012. $B$-cell-lineage immunogen design in vaccine development with HIV-1 as a case study. Nat Biotechnol, 30: 423-433.

Higo-Moriguchi K, Akahori Y, Iba Y, Kurosawa Y, and Taniguchi K. 2004. Isolation of human monoclonal antibodies that neutralize human rotavirus. J Virol, 78: 3325-3332.

Huang C C, Tang M, Zhang M Y, Majeed S, Montabana E, Stanfield R L, Dimitrov D S, Korber B, Sodroski J, Wilson I A, Wyatt R, and Kwong P D. 2005. Structure of a V3-containing HIV-1 gp120 core. Science, 310: 1025-1028.

Huang C C, Venturi M, Majeed S, Moore M J, Phogat S, Zhang M Y, Dimitrov D S, Hendrickson W A, Robinson J, Sodroski J, Wyatt R, Choe H, Farzan M, and Kwong P D. 2004. Structural basis of tyrosine sulfation and $\mathrm{VH}$-gene usage in antibodies that recognize the HIV type 1 coreceptor-binding site on gp120. Proc Natl Acad Sci U S A, 101: 2706-2711.

Hwang W C, Lin Y, Santelli E, Sui J, Jaroszewski L, Stec B, Farzan M, Marasco W A, and Liddington R C. 2006. Structural basis of neutralization by a human anti-severe acute respiratory syndrome spike protein antibody, 80R. J Biol Chem, 281: 34610-34616.

Jacobs S A, Diem M D, Luo J, Teplyakov A, Obmolova G, Malia T, Gilliland G L, and O'Neil K T. 2012. Design of novel FN3 domains with high stability by a consensus sequence approach. Protein Engineering Design \& Selection, 25: 107-117.

Kajihara M, Marzi A, Nakayama E, Noda T, Kuroda M, Manzoor R, Matsuno K, Feldmann H, Yoshida R, Kawaoka Y, and Takada A. 2012. Inhibition of Marburg virus budding by nonneutralizing antibodies to the envelope glycoprotein. J Virol, 86: 13467-13474.

Kaufmann B, Vogt M R, Goudsmit J, Holdaway H A, Aksyuk A A, Chipman P R, Kuhn R J, Diamond M S, and Rossmann M G. 2010. Neutralization of West Nile virus by cross-linking of its surface proteins with Fab fragments of the human monoclonal antibody CR4354. Proc Natl Acad Sci U S A, 107: 18950-18955.

Koide A, Wojcik J, Gilbreth R N, Hoey R J, and Koide S. 2012. Teaching an old scaffold new tricks: monobodies constructed using alternative surfaces of the FN3 scaffold. J Mol Biol, 415: 
393-405.

Kwong P D, and Mascola J R. 2012. Human antibodies that neutralize HIV-1: identification, structures, and B cell ontogenies. Immunity, 37: 412-425.

Kwong P D, Wyatt R, Robinson J, Sweet R W, Sodroski J, and Hendrickson W A. 1998. Structure of an HIV gp120 envelope glycoprotein in complex with the CD4 receptor and a neutralizing human antibody. Nature, 393: 648-659.

Lee J E, Fusco M L, Hessell A J, Oswald W B, Burton D R, and Saphire E O. 2008. Structure of the Ebola virus glycoprotein bound to an antibody from a human survivor. Nature, 454: 177-182.

Lee J E, Kuehne A, Abelson D M, Fusco M L, Hart M K, and Saphire E O. 2008. Complex of a protective antibody with its Ebola virus GP peptide epitope: unusual features of a $\mathrm{V}$ lambda $\mathrm{x}$ light chain. J Mol Biol, 375: 202-216.

Li F, Li W, Farzan M, and Harrison S C. 2005. Structure of SARS coronavirus spike receptor-binding domain complexed with receptor. Science, 309: 1864-1868.

Lindesmith L C, Beltramello M, Donaldson E F, Corti D, Swanstrom J, Debbink K, Lanzavecchia A, and Baric R S. 2012. Immunogenetic mechanisms driving norovirus GII.4 antigenic variation. PLoS Pathog, 8: e1002705.

Marasco W A, and Sui J. 2007. The growth and potential of human antiviral monoclonal antibody therapeutics. Nat Biotechnol, 25 : 1421-1434.

Marzi A, Yoshida R, Miyamoto H, Ishijima M, Suzuki Y, Higuchi M, Matsuyama Y, Igarashi M, Nakayama E, Kuroda M, Saijo M, Feldmann F, Brining D, Feldmann H, and Takada A. 2012. Protective efficacy of neutralizing monoclonal antibodies in a nonhuman primate model of Ebola hemorrhagic fever. PLoS ONE, 7: e36192.

Meng X, and Xiang Y. 2012. Generation and characterization of monoclonal antibodies specific for vaccinia virus. Methods Mol Biol, 890: 219-232.

Meuleman P, Catanese M T, Verhoye L, Desombere I, Farhoudi A, Jones C T, Sheahan T, Grzyb K, Cortese R, Rice C M, Leroux-Roels G, and Nicosia A. 2012. A human monoclonal antibody targeting scavenger receptor class $\mathrm{B}$ type $\mathrm{I}$ precludes hepatitis $\mathrm{C}$ virus infection and viral spread in vitro and in vivo. Hepatology, 55: 364-372.

Migone T S, Subramanian G M, Zhong J, Healey L M, Corey A, Devalaraja M, Lo L, Ullrich S, Zimmerman J, Chen A, Lewis M, Meister G, Gillum K, Sanford D, Mott J, and Bolmer S D. 2009. Raxibacumab for the treatment of inhalational anthrax. $\mathrm{N}$ Engl $\mathrm{J}$ Med, 361: 135-144.

Muster T, Steindl F, Purtscher M, Trkola A, Klima A, Himmler G, Ruker F, and Katinger H. 1993. A conserved neutralizing epitope on gp41 of human immunodeficiency virus type 1. J Virol, 67: 6642-6647.

Nakauchi M, Fukushi S, Saijo M, Mizutani T, Ure A E, Romanowski V, Kurane I, and Morikawa S. 2009. Characterization of monoclonal antibodies to Junin virus nucleocapsid protein and application to the diagnosis of hemorrhagic fever caused by South American arenaviruses. Clin Vaccine Immunol, 16: 1132-1138.

Nikolov D B, Broder C C, and et al. Submitted.

Nybakken G E, Oliphant T, Johnson S, Burke S, Diamond M S, and Fremont D H. 2005. Structural basis of West Nile virus neutralization by a therapeutic antibody. Nature, 437: 764-769.

Ohta A, Fujita A, Murayama T, Iba Y, Kurosawa Y, Yoshikawa T, and Asano Y. 2009. Recombinant human monoclonal antibodies to human cytomegalovirus glycoprotein $B$ neutralize virus in a complement-dependent manner. Microbes Infect, 11: 1029-1036.

Oliphant T, Engle M, Nybakken G E, Doane C, Johnson S, Huang L, Gorlatov S, Mehlhop E, Marri A, Chung K M, Ebel G D, Kramer L D, Fremont D H, and Diamond M S. 2005. Development of a humanized monoclonal antibody with therapeutic potential against West Nile virus. Nat Med, 11: 522-530.

Pak J E, Sharon C, Satkunarajah M, Auperin T C, Cameron C M, Kelvin D J, Seetharaman J, Cochrane A, Plummer F A, Berry J D, and Rini J M. 2009. Structural insights into immune recognition of the severe acute respiratory syndrome coronavirus $S$ protein receptor binding domain. J Mol Biol, 388: 815-823.

Prabakaran P, Streaker E, Chen W, and Dimitrov D S. 2011. 454 antibody sequencing-error characterization and correction. BMC Research Notes: In Press.

Prabakaran P, Gan J, Wu Y Q, Zhang M Y, Dimitrov D S, and Ji X. 2006. Structural mimicry of CD4 by a cross-reactive HIV-1 neutralizing antibody with CDR-H2 and $\mathrm{H3}$ containing unique motifs. $\mathrm{J}$ Mol Biol, 357: 82-99.

Prabakaran P, Zhu Z, Xiao X, Biragyn A, Dimitrov A S, Broder C C, and Dimitrov D S. 2009. Potent human monoclonal antibodies against SARS CoV, Nipah and Hendra viruses. Expert Opin Biol Ther, 9: 355-368.

Prabakaran P, Zhu Z, Chen W, Gong R, Feng Y, Streaker E, and Dimitrov D S. 2012. Origin, diversity, and maturation of human antiviral antibodies analyzed by high-throughput sequencing. Front Microbiol, 3: 277.

Prabakaran P, Gan J, Feng Y, Zhu Z, Choudhry V, Xiao X, Ji X, and Dimitrov D S. 2006. Structure of severe acute respiratory syndrome coronavirus receptor-binding domain complexed with neutralizing antibody. $\mathrm{J}$ Biol Chem, 281: 15829-15836.

Qiu X, Alimonti J B, Melito P L, Fernando L, Stroher U, and Jones S M. 2011. Characterization of Zaire ebolavirus glycoprotein-specific monoclonal antibodies. Clin Immunol, 141: 218-227.

Rani M, Bolles M, Donaldson E F, Van Blarcom T, Baric R, Iverson B, and Georgiou G. 2012. Increased antibody affinity confers broad in vitro protection against escape mutants of severe acute respiratory syndrome coronavirus. J Virol, 86: 9113-9121.

Reichert J M. 2008. Monoclonal Antibodies as Innovative Therapeutics. Current Pharmaceutical Biotechnology, 9: 423-430.

Saijo M, Tang Q, Shimayi B, Han L, Zhang Y, Asiguma M, Tianshu D, Maeda A, Kurane I, and Morikawa S. 2005. Antigen-capture enzyme-linked immunosorbent assay for the diagnosis of crimeancongo hemorrhagic fever using a novel monoclonal antibody. J Med Virol, 77: 83-88.

Sanchez M D, Pierson T C, McAllister D, Hanna S L, Puffer B A, Valentine L E, Murtadha M M, Hoxie J A, and Doms R W. 2005. Characterization of neutralizing antibodies to West Nile virus. Virology, 336: 70-82.

Schrama D, Reisfeld R A, and Becker J C. 2006. Antibody targeted drugs as cancer therapeutics. Nature Reviews Drug Discovery, 5: 147-159.

Scott L J, and Lamb H M. 1999. Palivizumab. Drugs, 58: 305-311; discussion 312-303.

Shedlock D J, Bailey M A, Popernack P M, Cunningham J M, Burton D R, and Sullivan N J. 2010. Antibody-mediated neutralization of Ebola virus can occur by two distinct mechanisms. Virology, 401: 228-235

Stiegler G, Kunert R, Purtscher M, Wolbank S, Voglauer R, Steindl F, and Katinger H. 2001. A potent cross-clade neutralizing human 
monoclonal antibody against a novel epitope on gp41 of human immunodeficiency virus type 1. Aids Research and Human Retroviruses, 17: 1757-1765.

Strokappe N, Szynol A, Aasa-Chapman M, Gorlani A, Forsman Quigley A, Hulsik D L, Chen L, Weiss R, de Haard H, and Verrips T. 2012. Llama antibody fragments recognizing various epitopes of the CD4bs neutralize a broad range of HIV-1 subtypes A, B and C. PLoS ONE, 7: e33298.

Sui J, Hwang W C, Perez S, Wei G, Aird D, Chen L M, Santelli E, Stec B, Cadwell G, Ali M, Wan H, Murakami A, Yammanuru A, Han T, Cox N J, Bankston L A, Donis R O, Liddington R C, and Marasco W A. 2009. Structural and functional bases for broad-spectrum neutralization of avian and human influenza A viruses. Nat Struct Mol Biol, 16: 265-273.

ter Meulen J, van den Brink E N, Poon L L, Marissen W E, Leung C S, Cox F, Cheung C Y, Bakker A Q, Bogaards J A, van Deventer E, Preiser W, Doerr H W, Chow V T, de Kruif J, Peiris J S, and Goudsmit J. 2006. Human monoclonal antibody combination against SARS coronavirus: synergy and coverage of escape mutants. PLoS Med, 3: e237.

Throsby M, van den Brink E, Jongeneelen M, Poon L L, Alard P, Cornelissen L, Bakker A, Cox F, van Deventer E, Guan Y, Cinatl J, ter Meulen J, Lasters I, Carsetti R, Peiris M, de Kruif J, and Goudsmit J. 2008. Heterosubtypic neutralizing monoclonal antibodies crossprotective against $\mathrm{H5N} 1$ and $\mathrm{H} 1 \mathrm{~N} 1$ recovered from human IgM+ memory B cells. PLoS ONE, 3: e3942.

Traggiai E, Becker S, Subbarao K, Kolesnikova L, Uematsu Y, Gismondo M R, Murphy B R, Rappuoli R, and Lanzavecchia A. 2004 An efficient method to make human monoclonal antibodies from memory B cells: potent neutralization of SARS coronavirus. Nature Medicine, 10: 871-875.

Trkola A, Purtscher M, Muster T, Ballaun C, Buchacher A, Sullivan N, Srinivasan K, Sodroski J, Moore J P, and Katinger H. 1996. Human monoclonal antibody 2 G12 defines a distinctive neutralization epitope on the gp120 glycoprotein of human immunodeficiency virus type 1. J Virol, 70: 1100-1108.

van Boheemen S, de Graaf M, Lauber C, Bestebroer T M, Raj V S, Zaki A M, Osterhaus A D, Haagmans B L, Gorbalenya A E, Snijder E J, and Fouchier R A. 2012. Genomic characterization of a newly discovered coronavirus associated with acute respiratory distress syndrome in humans. MBio, 3.

van Gils M J, and Sanders R W. 2013. Broadly neutralizing antibodies against HIV-1: templates for a vaccine. Virology, 435: 46-56.

Verkoczy L, Kelsoe G, Moody M A, and Haynes B F. 2011. Role of immune mechanisms in induction of HIV-1 broadly neutralizing antibodies. Curr Opin Immunol, 23: 383-390.

Waldmann T A. 2003. Immunotherapy: past, present and future. Nature Medicine, 9: 269-277.

Weiner L M, Dhodapkar M V, and Ferrone S. 2009. Monoclonal antibodies for cancer immunotherapy. Lancet, 373: 1033-1040.

Whittle J R, Zhang R, Khurana S, King L R, Manischewitz J, Golding H, Dormitzer P R, Haynes B F, Walter E B, Moody M A, Kepler T B, Liao H X, and Harrison S C. 2011. Broadly neutralizing human antibody that recognizes the receptor-binding pocket of influenza virus hemagglutinin. Proc Natl Acad Sci U S A, 108: 14216-14221.

Wilson J A, Hevey M, Bakken R, Guest S, Bray M, Schmaljohn A L, and Hart M K. 2000. Epitopes involved in antibody-mediated protection from Ebola virus. Science, 287: 1664-1666.
Xiao X, Feng Y, Vu B K, Ishima R, and Dimitrov D S. 2009. A large library based on a novel (CH2) scaffold: identification of HIV-1 inhibitors. Biochem Biophys Res Commun, 387: 387-392.

Xiao X, Chen W, Feng Y, Zhu Z, Prabakaran P, Wang Y, Zhang M Y, Longo N S, and Dimitrov D S. 2009. Germline-like predecessors of broadly neutralizing antibodies lack measurable binding to HIV-1 envelope glycoproteins: implications for evasion of immune responses and design of vaccine immunogens. Biochem Biophys Res Commun, 390: 404-409.

Xiao X D, Chen W Z, Feng Y, and Dimitrov D S. 2009. Maturation Pathways of Cross-Reactive HIV-1 Neutralizing Antibodies. Viruses-Basel, 1: 802-817.

Xu K, Rajashankar K R, Chan Y P, Himanen J P, Broder C C, and Nikolov D B. 2008. Host cell recognition by the henipaviruses: crystal structures of the Nipah $G$ attachment glycoprotein and its complex with ephrin-B3. Proc Natl Acad Sci U S A, 105: 9953-9958.

Yang Z Y, Werner H C, Kong W P, Leung K, Traggiai E, Lanzavecchia A, and Nabel G J. 2005. Evasion of antibody neutralization in emerging severe acute respiratory syndrome coronaviruses. Proc Natl Acad Sci U S A, 102: 797-801.

Ye J Q, Shao H X, and Perez D R. 2012. Passive immune neutralization strategies for prevention and control of influenza $A$ infections. Immunotherapy, 4: 175-186.

Ying T, Chen W, Gong R, Feng Y, and Dimitrov D S. 2012. Soluble monomeric IgG1 Fc. J Biol Chem, 287: 19399-19408.

Zhang M Y, Choudhry V, Xiao X, and Dimitrov D S. 2005. Human monoclonal antibodies to the $S$ glycoprotein and related proteins as potential therapeutics for SARS. Curr Opin Mol Ther, 7: 151-156.

Zhang M Y, Xiao X, Sidorov I A, Choudhry V, Cham F, Zhang P F, Bouma P, Zwick M, Choudhary A, Montefiori D C, Broder C C, Burton D R, Quinnan G V, Jr., and Dimitrov D S. 2004. Identification and characterization of a new cross-reactive human immunodeficiency virus type 1-neutralizing human monoclonal antibody. J Virol, 78: 9233-9242.

Zhu Z, Bossart K N, Bishop K A, Crameri G, Dimitrov A S, McEachern J A, Feng Y, Middleton D, Wang L F, Broder C C, and Dimitrov D S. 2008. Exceptionally potent cross-reactive neutralization of Nipah and Hendra viruses by a human monoclonal antibody. $J$ Infect Dis, 197: 846-853.

Zhu Z, Dimitrov A S, Bossart K N, Crameri G, Bishop K A, Choudhry V, Mungall B A, Feng Y R, Choudhary A, Zhang M Y, Feng Y, Wang L F, Xiao X, Eaton B T, Broder C C, and Dimitrov D S. 2006. Potent neutralization of Hendra and Nipah viruses by human monoclonal antibodies. J Virol, 80: 891-899.

Zhu Z, Chakraborti S, He Y, Roberts A, Sheahan T, Xiao X, Hensley L E, Prabakaran P, Rockx B, Sidorov I A, Corti D, Vogel L, Feng Y, Kim J O, Wang L F, Baric R, Lanzavecchia A, Curtis K M, Nabel G J, Subbarao K, Jiang S, and Dimitrov D S. 2007. Potent cross-reactive neutralization of SARS coronavirus isolates by human monoclonal antibodies. Proc Natl Acad Sci U S A, 104: 12123-12128.

Zhu Z, Qin H R, Chen W, Zhao Q, Shen X, Schutte R, Wang Y, Ofek G, Streaker E, Prabakaran P, Fouda G G, Liao H X, Owens J, Louder M, Yang Y, Klaric K A, Moody M A, Mascola J R, Scott J K, Kwong P D, Montefiori D, Haynes B F, Tomaras G D, and Dimitrov D S. 2011. Cross-reactive HIV-1-neutralizing human monoclonal antibodies identified from a patient with 2F5-like antibodies. J Virol, 85: 11401-11408. 